\title{
Physico-Chemical and Heavy Metal Profiles of Marine, Borehole and Sea Water
}

\author{
MADU, A. N., AGBASI, U. M and UZOMA, E. I.
}

\begin{abstract}
The extent of water pollution on some rivers and lagoons within Badagry and its environs in Lagos State Nigeria has been critical analyzedwith respect to the physico-chemical properties of the surface and underground waters and the results show that total dissolved solids for sea water ranged from 4523-4408 ppm, lagoon water 622-1471 ppm and borehole water 250-61 ppm. Total suspended solid for sea water ranged from 422-231 ppm, lagoon water 129-133 ppm and borehole water 41-146 ppm. Salinity values for sea water ranged from 0.3-0.3 ppm, lagoon 0.5-0.3 ppm and borehole water 0.1-0.3 ppm. Methyl orange alkalinity for sea water ranged from $3.5-3.0 \mathrm{ppm}$, lagoon water 1.1-1.0 ppm and borehole water 0.5-0.8 ppm. Phenolphthalein alkalinity for sea water ranged from 0.4-0.2 ppm, lagoon water 0.2-0.3 ppm and borehole water 0.1-0.2 ppm. Specific gravity for sea water ranged from 16.371-16.407 ppm, lagoon water 15.878-15.673 ppm and borehole water 15.554-15.839 ppm. Heavy metals such as $\mathrm{Ca}^{2+}$ for sea water ranged from 436-427, lagoon water 497-488 and borehole water $345-336 . \mathrm{Mg}^{2+}$ for sea water ranged from 128-136, lagoon water 133-189 and borehole water 112-116. $\mathrm{Fe}^{2+}$ for sea water ranged from 2.546-2.512, lagoon water 2,786-2.869 and borehole water 1.465-1.354. $\mathrm{Cu}^{2+}$ for sea water ranged from 2.84-2.62, lagoon water 3.86-3.86 and borehole water $0.84-0.93 . \mathrm{Mn}^{2+}$ for sea water ranged from $0.756-$ 0.726 , lagoon water 1.026-1.022 and borehole water $0.450-0.470 . \mathrm{Cr}^{2+}$ for sea water ranged from 1.071.248, lagoon water 1.897-1.957 and borehole water 0.026-0.028. Bio-chemical analysis such as temperature for sea water ranged from $27.5-28.5{ }^{\circ} \mathrm{C}$, lagoon water $29.8-28.7{ }^{\circ} \mathrm{C}$ and borehole water 27.6$27.8^{\circ} \mathrm{C} . \mathrm{pH}$ for sea water ranged from 6.8-6.8, lagoon water 6.9-7.0 and borehole 7.3-7.2. BOD and COD in see water ranged from 754-766; 1876-1833 mg/l respectively, lagoon water 978-986; 1943-1982 mg/l respectively whereas the dissolved oxygen for borehole water ranged from 5.54-5.66 mg/l
\end{abstract}

Key Words : Marine, sea water, heavy metals, Badagry and borehole.

Water pollution and its impacts on the environment have been of serious concern for environmental and industrial experts in the present world. However, to mitigate water pollution and improve the water quality, advanced waste water treatment technologies need to be evoked. These technologies can be accomplished by removing the physical, chemical and biological materials that constitute contaminants from waste water and producing an environmentally safe treated effluent and a solid waste, (Bradley et al, 2014; Mancy, 1971). When untreated waste water enters into the surface and ground water resources, serious environmental and human health risk are the obvious result, (Tchobanoglouset al, 1991). In other to minimize the potential risks from untreated waste water entering freshwater resources, industrial waste water plants go through a water quality assessment by monitoring some parameters. Water quality professionals assess water quality by measuring the concentrations of these parameters and comparing with their known standards (Mancy, 1971; Moret al, 2006). Biochemical oxygen demand, chemical oxygen demand, taste, odor, color, chlorine demand, hardness, alkalinity and biodegradability tests are 
some of the unique analytical parameters of the water pollution (Mancy, 1971; Henzeet al., 2002).

Excessive levels of some of these parameters often serve as an early warning of problems arising from pollution. Some of these parameters are COD and BOD which indicate the amount of organic pollution and water degradation. There are two major sources of water pollutionwhich include the 'point' sources and 'diffused' sources. Point sources are those sources which can be identified at a single location are known as point sources.Minimization ofpollution caused by point sources in all domestic sewage, industrial effluents, cattle field and livestock waste-water etc. can be effected if the wastes are centrally collected, treated up to requisite tolerable level and possibly recycledto serve different useful purposes.Diffused Source however aresources whose location cannot be easily identified are called diffused sources. The water pollution caused by diffused sources like agriculture can be controlled by changing the cropping patterns, tillage particles and advanced farm management practices which do not contaminate the water bodies.Pollution of river bodies has become a major and global problem that is becoming critical in developing nations of the world because of inadequacy or non-existence of surface water quality protection measures and sanitation.

Lagoons, rivers, and streams are sinks for wastes. The discharges of domestic and industrial waste as well as oil spills pose threats to the dilution abilities of the oceans, lagoons, and rivers in major cities (World Bank 1995; UNESCO 2006; Krantzet al, 2007). Heavily polluted water may travel long distances in days before a significant degree of purification is achieved since the natural purification of polluted waters in itself is never fast (Chapman, 1992; Henry et al, 2005; Garg, 2006). This in effect makes pollution of river bodies a global issue that has no respect for national or international boundaries. The protection of the aquatic life of any potential receiving water body therefore calls for an effective determination of its capacity to assimilate wastes. Hence, constant assessments of the hydraulic and water quality conditions of receiving water bodies are very critical to effective planning and management.The dissolved oxygen (DO) and the biochemical oxygen demand (BOD) are two useful parameters in tracing pollution profile and natural purification of rivers upon which engineering calculations of permissible pollution loads are based (Fair et al, 1971; Garg, 2006). The BOD defines in a comprehensive manner the degradable load added to the receiving water body or remaining in it. It is both time and place specific. BOD therefore measures the oxygen absorbing capacity of an effluent. The DO defines the capacity of the body of water to assimilate the imposed load by itself or with the help of reaeration through oxygen absorbed mainly from the atmosphere and also through photosynthesis. The amount of dissolved oxygen that can be held by the water depends mainly on the water temperature (Garg, 2006; Agunwambaet al, 2006). The determination of dissolved oxygen concentration relative to its saturation value and the rate of oxygen utilization measured as its BOD become a good measure for identifying the pollution status of a water body. The progressive utilization of oxygen in water bodies has been widely studied over the years and has been used as a measure of the amount of decomposable or organic matter contained in it at a given time.Determination of the self-purification capacity of water bodies has been the subject of researches by scientists around the world (Villeneuve et al, 1998; Rounds, 2001; Radwanet al, 2003; Agunwamba et al., 2006; Alamet al, 2007).

A rapid development in science and technology and a vast usage of industrial processes are generating and releasing more and more 
pollutants into the environment. The analysis of chemical pollutants in water therefore has become a serious concern to the professional world and to the authorities in charge of water quality (Chen et al, 2014; World Health Organization, 1993). Water quality depends on these parameters and their characterization tests (Henze, 2002). Acidity of water is determined when reacts with a strong base to a designated $\mathrm{pH}$. Acidity is a measure of an aggregate property of water, and which can be interpreted in terms of specific substances only when the chemical composition of the sample is known (American Public Health Association, 1995; Henze, 2002).

Acidity is classified by the $\mathrm{pH}$ value of a titration end point. Acidity caused by mineral acids contains a pH below 4.5 (Cheremisinoff et al, 2015). Industrial waste waters containing high mineral acidity must be neutralized before they are subjected to biological treatment or direct discharge to water sources. A standard method for the examination of water and waste water recommends titration with sodium hydroxide to an end point $\mathrm{pH}$ of 3.7 to determine mineral acidity (American Journal of Public Health, 1915). Alkalinity of water indicates the presence of bicarbonate, carbonate, and hydroxide ions. In waste water treatment, alkalinity is a quality parameter to determine the amenability of waste to the treatment process (Henze, 2002). Waste water becomes alkaline when receiving alkalinity from the water supply, ground water, domestic use (detergents and soap-based products) and acid rain (American Public Health Association, 1995). Alkalinity is significant in the treatment processes for water and waste water. Alkalinity is expressed as phenolphthalein alkalinity or total alkalinity (American Journal of Public Health, 1915). Both types can be determined by titration with a standard sulfuric acid solution to an end point $\mathrm{pH}$, evidenced by the color change of a standard indicator solution. The $\mathrm{pH}$ also can be determined with a $\mathrm{pH}$ meter. Phenolphthalein alkalinity is determined by titration to a $\mathrm{pH}$ of 8.3 (the phenolphthalein end point) (American Journal of Public Health, 1915). Conductivity is a measure of how substances like oil, alcohol, and sugar present in water conduct impose conductivity on it, (Murdoch et al, 1996).

The measurement of conductivity is generally expressed in $\mathrm{S} / \mathrm{cm}$ (or $\mathrm{m} \mathrm{S} / \mathrm{cm}$ ). The scale for conductivity starts at $0.05 \mu \mathrm{S} / \mathrm{cm}$ (at 25 C) for ultra-pure water (Cable, 2005). The suspended solids are equal to the weight difference between the dissolved solids and the total solids (Murdoch et al., 1996). Components of the total solid load from the treatment plants include phosphorus, nitrogen, and organic matter.The amount of solids in waste water is frequently used to describe the strength of the waste. Gravimetric analysis is the approved procedure for determining total solids, total dissolved solids and total suspended solids, fixed and volatile solids while volumetric analysis is the method for measuring settle-able solids (American Journal of Public Health, 1915). COD is the amount of dissolved oxygen to oxidize and stabilize a sample when organic or inorganic matter of sample solution is responsive by a strong chemical oxidant. The COD value indicates the mass of oxygen consumed per liter of solution and expressed in milligrams per liter $(\mathrm{mg} / \mathrm{L})$. The higher the chemical oxygen demand, the higher the amount of pollution in the water sample. However, COD is considered one of the important quality control parameter of an effluent in waste water treatment facility ( $\mathrm{Wu}$ et al, 2011). The complete oxidation of organic compounds under such strong oxidizing conditions produces carbon dioxide $\left(\mathrm{CO}_{2}\right)$ and water $\left(\mathrm{H}_{2} \mathrm{O}\right)$. The $\mathrm{COD}$ for any organic compound can be theoretically calculated from writing a balanced equation (Boyles, 1997). Theoretically infinite time is required for complete biological oxidation of organic matter of domestic sewage. 
Water samples are to be kept at $200^{\circ} \mathrm{C}$ for proper biodegrading even whenit has impact on dissolved oxygen and thus BOD (Pitter et al., 1990). A corelation exists between $\mathrm{COD}$ and $\mathrm{BOD}_{5}$ and $\mathrm{BOD}_{5} / \mathrm{COD}$ ratioknown as biodegradability index and when domestic waste waters are involved, this value varies from 0.4 to 0.8 (Srinivas, 2008). If $\mathrm{BOD}_{5} / \mathrm{COD}$ is $\leqq 0.6$ then the waste is fairly biodegradable and an effective biological treatment can be possible. If $\mathrm{BOD}_{5} / \mathrm{COD}$ ratio is between 0.3 and 0.6 , then seeding is required to treat it biologically. If $\mathrm{BOD}_{5} / \mathrm{COD}$ ratio is $<0.3$ then the probability of biological treatment is low (Srinivas, 2008). The research aim at determining the physico-chemical and heavy metal profiles of marine, borehole and sea water within Badagry area and to assess to what extent the industries within impact on both the surface and underground waters within the area.

\section{MATERIALS AND METHODS}

All samples were collected during the morning hours in Badagry Lagos state Nigeria.

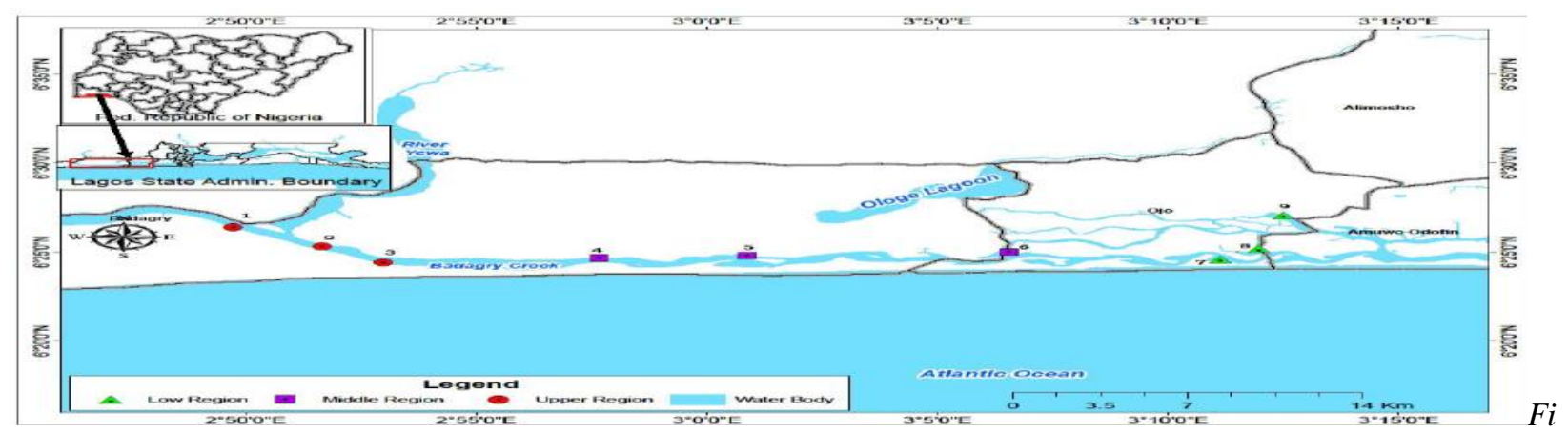

g. 1. Geographical map of Badagry where the samples were collected.

Twelve sampling sites were selected for the sample collection from where water samples were collected. Five samples were collected from the Badagry creek, five samples collected from the ocean and two borehole samples from residence in Badagry. All samples were collected in a clean transparent plastic container and properly labeled before returning to the laboratory. 


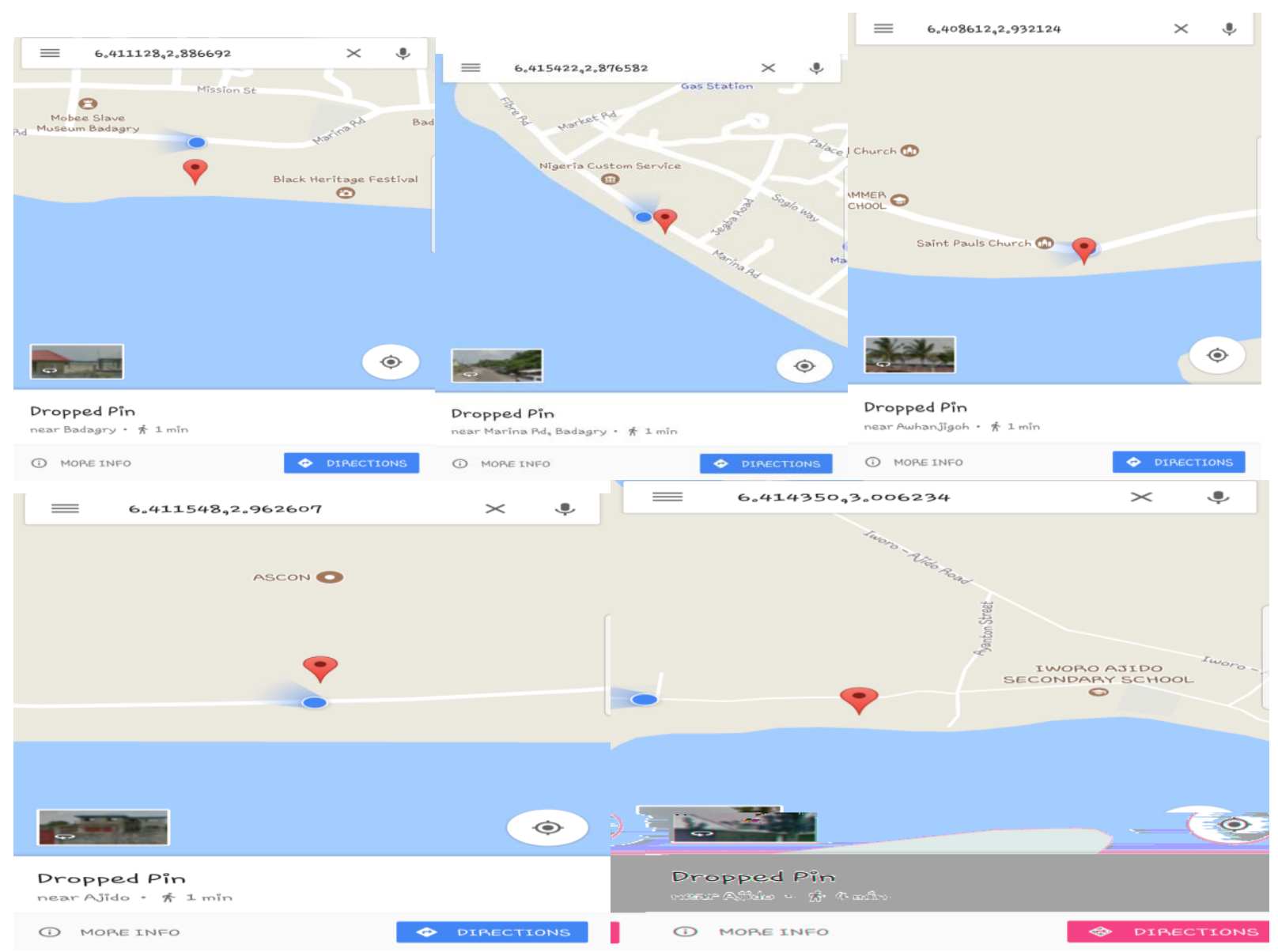

Fig. 2. Locations and GPRS where the samples were collected

The TDS and TSS were determined in the usual manner by filtration, weighing and drying while the salinity was determined by Robert Boyle's method in which $\mathrm{AgCl}$ was precipitated sing $\mathrm{AgNO}_{3}$. The phenolphthalein and methyl orange alkalinities were determined as by titration with $\mathrm{HCl}$ using the respective indicators. The pycnometer method was used to determine the specific gravities whereas the TOLEDO's conductimeter was used to determine the conductivity. The BOD and COD were determined using the manometric method using the $\mathrm{HACH}$ manometer. The dissolved metals were measured using the Absorption Spectrophotometer make; THERMOSCIENTIFIC ICE TM 3000 SERIES with dedicated flame and furnace, BUSCH and LOMD colorimeter was used to determine the anions of sulphate, nitrate and chloride, while the HANNA turbidimeter was used to determine the turbidity of the water sample.

\section{RESULTS}

The extent of water pollution on some rivers and State Nigeria has been successfully investigated lagoons within Badagry and its environs in Lagos and results obtained are as shown: 


\begin{tabular}{|l|l|l|l|l|l|l|}
\hline $\begin{array}{l}\text { Water } \\
\text { sample }\end{array}$ & $\begin{array}{l}\text { TDS } \\
(\mathrm{ppm})\end{array}$ & $\begin{array}{l}\text { TSS } \\
(\mathrm{ppm})\end{array}$ & $\begin{array}{l}\text { Specific } \\
\text { Gravity }\end{array}$ & $\begin{array}{l}\text { Deviation TDS } \\
(\mathrm{ppm})\end{array}$ & $\begin{array}{l}\text { Deviation } \\
\text { TSS(ppm) }\end{array}$ & $\begin{array}{l}\text { Deviation } \\
(\mathrm{ppm})\end{array}$ \\
\hline A1 & 4523 & 422 & 1.637 & 4023 & 387 & 13.871 \\
\hline B1 & 4384 & 380 & 1.636 & 3884 & 345 & 13.866 \\
\hline C1 & 4439 & 164 & 1.618 & 3939 & 129 & 13.689 \\
\hline D1 & 4446 & 378 & 1.621 & 3946 & 343 & 13.710 \\
\hline E1 & 4408 & 231 & 1.640 & 3908 & 196 & 13.907 \\
\hline A2 & 662 & 129 & 1.587 & 162 & 94 & 13.378 \\
\hline B2 & 944 & 125 & 1.573 & 444 & 90 & 13.370 \\
\hline C2 & 1065 & 105 & 1.580 & 565 & 61 & 13.179 \\
\hline D2 & 1339 & 96 & 1.567 & 839 & 98 & 13.173 \\
\hline E2 & 1471 & 133 & 1.567 & 971 & 6 & 13.339 \\
\hline Borehole 1 & 7.652 & 1.084 & 1.554 & 250 & 439 & 111 \\
\hline Borehole 2 & 8.346 & 1.426 & 1.583 & & & 654 \\
\hline
\end{tabular}

Table 1.TDS, TSS and specific gravity values for water sampleAction limits; TDS $(\mathrm{ppm})=500, \mathrm{SG}(\mathrm{ppm})=2.5$

\begin{tabular}{|l|l|l|l|l|l|l|}
\hline $\begin{array}{l}\text { Water } \\
\text { sample }\end{array}$ & $\begin{array}{l}\text { Methyl orange } \\
\text { MOA }(\mathrm{mL})\end{array}$ & $\begin{array}{l}\text { Phenolphthalein } \\
\text { PA }(\mathrm{mL})\end{array}$ & $\begin{array}{l}\text { Salinity } \\
(\mathrm{mL})\end{array}$ & $\begin{array}{l}\text { Deviation MO (ppm) } \\
\text { from Action Limit }\end{array}$ & $\begin{array}{l}\text { Deviation PA (ppm) } \\
\text { from Action Limit }\end{array}$ & $\begin{array}{l}\text { Deviation SA (ppm) } \\
\text { from Action Limit }\end{array}$ \\
\hline A1 & 3.5 & 0.4 & 0.3 & 0.2 & 7.9 & 34.7 \\
\hline B1 & 2.9 & 0.3 & 0.5 & 0.8 & 8.0 & 34.5 \\
\hline C1 & 3.0 & 0.2 & 0.6 & 0.7 & 8.1 & 34.4 \\
\hline D1 & 3.3 & 0.3 & 0.4 & 0.4 & 8.0 & 34.6 \\
\hline E1 & 3.0 & 0.2 & 0.3 & 0.7 & 8.1 & 34.7 \\
\hline A2 & 1.1 & 0.2 & 0.5 & 2.6 & 8.1 & 0 \\
\hline B2 & 0.8 & 0.1 & 0.3 & 2.9 & 8.2 & 0.2 \\
\hline C2 & 1.0 & 0.2 & 0.2 & 2.7 & 8.1 & 0.3 \\
\hline D2 & 0.8 & 0.1 & 0.4 & 2.9 & 8.2 & 0.2 \\
\hline E2 & 1.0 & 0.3 & 0.3 & 2.7 & 8.0 & 0.3 \\
\hline Borehole 1 & 0.5 & 0.1 & 0.2 & 3.2 & 8.2 & 0.4 \\
\hline Borehole 2 & 0.8 & 0.2 & 0.1 & 2.9 & 0.2 & \\
\hline NaCl & 0.8 & 0.1 & 0.3 & 2.9 & & 0.2 \\
\hline
\end{tabular}


DEV SANSKRITI: Interdisciplinary International Journal (2018), 12, 67-77

Table 2.Methyl orange, phenolphthalein Alkalinity and salinity values for samples. Action limits; $(\mathrm{ppm})=3.7$, salinity $(\mathrm{ppm})=$ $35 \mathrm{ppt}$ in ocean water; 0.5 in river water

\begin{tabular}{|c|c|c|c|c|c|c|c|c|c|c|c|c|}
\hline Sample Metal mg/L & A1 & B1 & $\mathrm{C} 1$ & D1 & E1 & $\mathrm{A} 2$ & B2 & $\mathrm{C} 2$ & D2 & E2 & Borehole 1 & Borehole 2 \\
\hline $\mathrm{Ca}^{2+}$ & 436 & 458 & 432 & 448 & 427 & 497 & 489 & 487 & 492 & 488 & 345 & 336 \\
\hline $\mathrm{Mg}^{2+}$ & 128 & 126 & 124 & 132 & 136 & 133 & 186 & 197 & 194 & 189 & 112 & 116 \\
\hline $\mathrm{Fe}^{2+}$ & 2.546 & 2.463 & 2.538 & 2.446 & 2.512 & 2.786 & 2.872 & 2.886 & 2.967 & 2.869 & 1.465 & 1.354 \\
\hline $\mathrm{Cu}^{2+}$ & 2.84 & 2.65 & 2.68 & 2.64 & 2.62 & 3.86 & 3.82 & 3.88 & 4.02 & 3.86 & 0.84 & 0.93 \\
\hline $\mathrm{Mn}^{2+}$ & 0.756 & 0.687 & 0.684 & 0.788 & 0.726 & 1.026 & 1.032 & 1.019 & 1.028 & 1.022 & 0.450 & 0.470 \\
\hline $\mathrm{Cr}^{2+}$ & 1.07 & 1.289 & 1.278 & 1.265 & 1.248 & 1.897 & 1.876 & 1.846 & 1.986 & 1.957 & 0.026 & 0.028 \\
\hline $\mathrm{Zn}^{2+}$ & 0.674 & 0.764 & 0.698 & 0.647 & 0.687 & 1.098 & 1.026 & 1.058 & 1.038 & 1.107 & 0.010 & 0.012 \\
\hline $\mathrm{As}^{2+}$ & 0.075 & 0.076 & 0.073 & 0.078 & 0.075 & 0.859 & 0.896 & 0.917 & 0.925 & 0.946 & 0.189 & 0.158 \\
\hline $\mathrm{Cd}^{2+}$ & 0.002 & 0.002 & 0.002 & 0.002 & 0.002 & 0.002 & 0.002 & 0.002 & 0.002 & 0.002 & 0.001 & 0.001 \\
\hline $\mathrm{Pb}^{2+}$ & 0.354 & 0.356 & 0.356 & 0.368 & 0.363 & 0.847 & 0.864 & 0.978 & 0.947 & 0.965 & 0.007 & 0.008 \\
\hline $\mathrm{Ni}^{2+}$ & 2.056 & 2.106 & 2.106 & 2.108 & 2.027 & 3.287 & 3.178 & 3.178 & 3.194 & 3.168 & 0.01 & 0.02 \\
\hline
\end{tabular}

Table 3: result of metal analysis. Action limit $=\mathrm{Ca}^{2+}=<75 ; \mathrm{Mg}^{2+}=<30 ; \mathrm{Fe}^{2+}=2.0 ; \mathrm{Cu}^{2+}=0.5 ; \mathrm{Mn}^{2+}=0.2 ; \mathrm{Cr}^{2+}=0.05$; $\mathrm{Zn}^{2+}=2.0 ; \mathrm{As}^{2+}=0.1 ; \mathrm{Cd}^{2+}=0.01 ; \mathrm{Pb}^{2+}=0.05 ; \mathrm{Ni}^{2+}=0.1$;

\begin{tabular}{|l|l|l|l|l|l|l|l|l|l|l|l|l|}
\hline Sample & A1 & B1 & C1 & D1 & E1 & A2 & B2 & C2 & D2 & E2 & Borehole1 & Borehole 2 \\
\hline Temp. ${ }^{\circ} \mathrm{C}$ & 27.5 & 28.41 & 27.9 & 29.6 & 28.5 & 29.8 & 28.9 & 28.6 & 28.9 & 28.7 & 27.612 & 27.823 \\
\hline $\mathrm{pH}$ & 6.82 & 6.72 & 6.74 & 6.82 & 6.83 & 6.94 & 6.93 & 7.04 & 7.12 & 7.04 & 7.324 & 7.241 \\
\hline Turbidity & 3.53 & 4.73 & 3.93 & 4.64 & 4.52 & 6.53 & 7.24 & 6.53 & 8.13 & 7.52 & 1.812 & 1.902 \\
\hline BOD mg/l & 754 & 765 & 760 & 756 & 766 & 978 & 967 & 965 & 978 & 986 & 1.435 & 1.643 \\
\hline $\mathrm{COD} \mathrm{mg/l}^{1876}$ & 1786 & 1854 & 1836 & 1833 & 1992 & 1943 & 1922 & 1937 & 1982 & 5.832 & 7.341 \\
\hline $\mathrm{SO}_{4}{ }^{2+} \mathrm{g} / \mathrm{l}$ & 14.51 & 14.32 & 14.23 & 14.81 & 14.62 & 17.91 & 17.23 & 17.74 & 17.42 & 17.13 & 5.562 & 7.681 \\
\hline $\mathrm{NO}^{3-} \mathrm{mg} / \mathrm{l}$ & 4.63 & 4.73 & 4.77 & 4.25 & 4.21 & 6.37 & 6.46 & 6.28 & 6.93 & 6.88 & 1.065 & 1.440 \\
\hline $\mathrm{Cl}^{-} \mathrm{g} / \mathrm{l}$ & 15.66 & 14.99 & 15.24 & 15.83 & 15.44 & 18.26 & 18.66 & 18.36 & 18.67 & 18.55 & 9.562 & 10.482 \\
\hline
\end{tabular}

Table 4. Results of Bio-chemical analyses for water samples Action limit $=\mathrm{Temp}=40 ; \mathrm{pH}=5-9$; Turbidity $=5.0$;
$\mathrm{BOD}=40$;
$\mathrm{COD}=120$;
$\mathrm{SO}_{4}{ }^{2+}=750$
$\mathrm{NO}^{3-}=1$;
$\mathrm{Cl}^{-}=750$;
$\mathrm{DO}=0-$ 

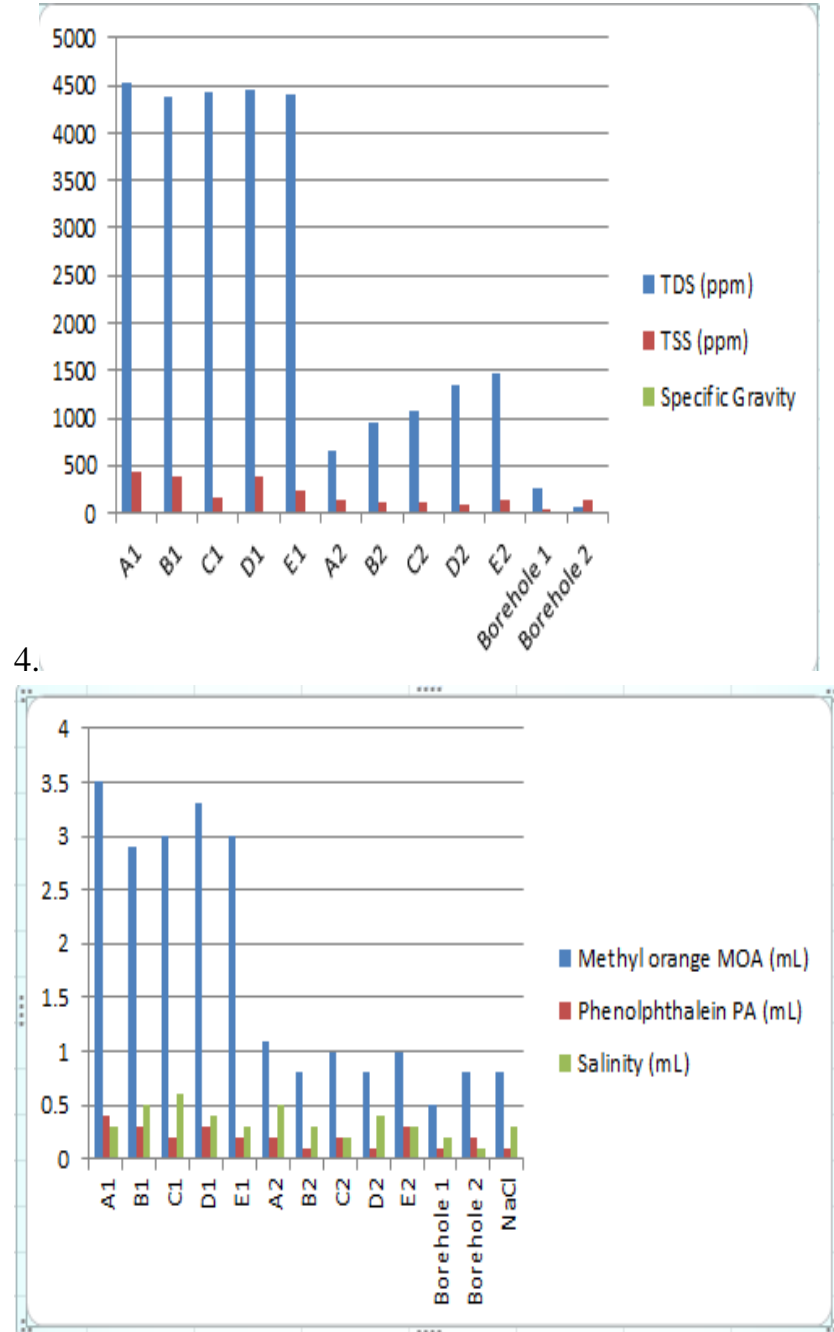

Fig.3: A bar chart showing (a) the TDS, TSS and specific gravity (b) Alkalinity and salinity values for water samples

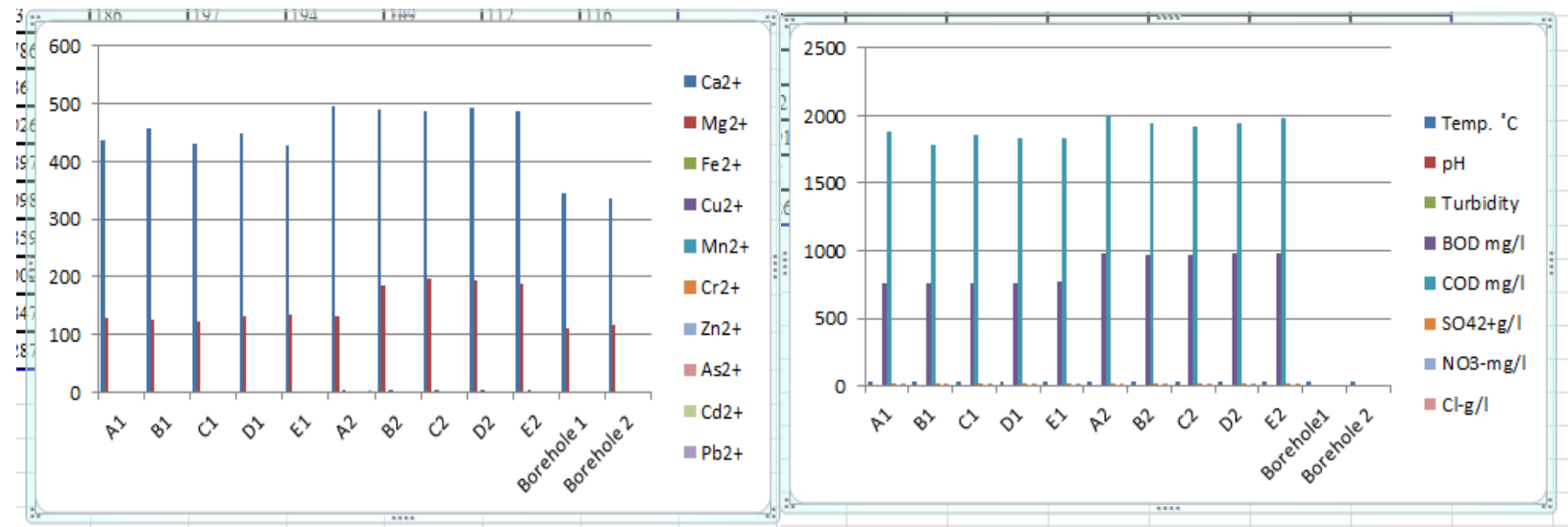

Fig.4: A bar chart showing (a) the concentration of heavy metals and (b) Biochemical properties of water samples 


\section{DISCUSSION}

This work aims at evaluating the extent to which the nearby industries impact on surface and underground water in Badagry and its environs with respect to adequacy of otherwise of their effluent discharge system. The values obtained for sea water for total dissolved solids were much higher than lagoon water and borehole water. This shows that the samples A1-E1 has high values of combined content of inorganic content that are found in water. The qualitative test results of total dissolved solid in samples A2-E2 and borehole1borehole2 shows that the water sample there are little inorganic content in them. High levels of TDS are often caused by the presence of potassium, chlorides and sodium. These ions have little or no short term effects, but toxic ions (lead, arsenic, cadmium, nitrate and others) may also be dissolved in water. The TDS for samples A1-E1 showed undesirably high values which could be salty, bitter, or metallic. It could also indicate the presence of toxic metals. These high values of TDS point to hard water, which causes scale buildup in pipes and valves reducing their performance. Total suspended Solids TSS are solids in water that can be trapped by filtration. TSS values for samples A1-E1 show high values as compared to values in sample A2-Borehole2 while samples A1E1 have more suspended solid than A2-Borehole2. Salinity measures the amount of salts in dissolved water. From the deviations it shows that there is high salinity in samples A1-E1, and little values of salinity in A2-Borehole2.The alkalinity values in samples A1-E1 are relatively low from the deviation showing that it is not suitable for drinking. The positive part of having alkalinity in water keeps it less susceptible to acids. Values in A1-E1 means that the water is packed with minerals and can cause water to become fogged. The specific gravity is a measure of relative density and the values obtained in samples A1-E1 show high specific gravity compared to A2Borehole2. The values of calcium $\mathrm{Ca}^{2+}$ and magnesium ions $\mathrm{Mg}^{2+}$ in samples A2-E2 presented high values showing that the water samples contain ions that cause hardness in water. Heavy metals ions generally were higher in samples A2E2 than samples A1-E1. Borehole1-Borehole2 show little amount of calcium and magnesium. The temperature values were observed to be normal within the ranges $25-30{ }^{\circ} \mathrm{C}$ in all water samples. High levels of COD and minimal levels of BOD in all sea and lagoonwater samples which mean that the waste water contains highly nonbiodegradable wastes.

\section{CONCLUSION}

Pollutants entering a river can be washed away to sea, or degraded by microorganisms present in the river. Excess pollution in a river can damage the plant and animal life present in the river by reducing the oxygen content of the water. Point sources of pollution are discharge points where pollutants collected by a network of pipes or channels are released. Diffuse sources, on the other hand, are characterized by multiple discharge points that cannot be located exactly. Point sources can be easily controlled, while diffuse sources pose great difficulty in terms of collection and control. Lakes are much more prone than rivers to pollution as they do not have the flushing effect of rivers. They also do not have the dilution effect of large bodies of water such as the sea. Eutrophication can be a particular problem for lakes. The major sources of water pollution will include discharges from sewage works, often containing industrial wastes, discharges from manufacturing and industrial plants, including mines, discharges from animal rearing, fish farming and agriculture, seepage from domestic and industrial landfill sites and urban surface 
water run-off. Different pollutants affect the aquatic environment in different ways. While at low concentrations many pollutants (e.g. organic materials, $\mathrm{N}$ and $\mathrm{P}$ ) may be beneficial, at high levels they can adversely affect the ecology of the system. Excess nitrate can be particularly harmful to babies. Many of the toxic pollutants in effluents are synthetic, and therefore do not easily biodegrade naturally. The effects of physical pollution on the ecology of a river system can be complex, affecting the feeding and breeding habits of the different species. Biological pollutants can spread disease through water, and also disrupt the ecology. The measurement and control of water quality is therefore of crucial importance in the interests of public health and the maintenance of the environment. Having all these in mind, it becomes very pertinent to ensure the quality of water used for drinking cooking, washing, industrial purposes and irrigation. The increased BOD and COD values are higher in lagoon water samples than sea water and borehole water. This is because the accumulations of industrial and vegetal wastes are heavy contaminants of lagoon water. The sea water has more dilution as the water flows past unlike lagoon water that is a receptacle to heavy industrial sewage. The heavy metals are also higher in lagoon in line with expectations. This is so because most industrial effluents are heavily loaded with heavy metals and mostly these come from ineffective sewage disposal system.

Madu, A. N., Uzoma, E. I Industrial Chemistry Department, Crawford University and . ${ }^{\mu}$ Agbasi, U. M, Department of Science Lab. Technology Imo State Polytechnic. Umuagwo, Nigeria

\section{REFERENCES}

1. Agunwamba JC, Maduka CN, Ofosaren AM (2006) Analysis of pollution status of Amadi Creek and its management. J Water Supply Res Technol-AQUA(55)6:427-435

2. Alam JB, Islam MR, Muyen Z, Mamun M, Islam S (2007) Water quality parameters along rivers. Int $\mathbf{J}$ Environ SciTechnol 4(1):159-167

3. American Public Health Association, (1995).American Water Works Association, Water Pollution Control Federation, and Water Environment Federation. Standard methods for the examination of water and waste water, volume 2. American Public Health Association.

4. American Public Health Association. (1995). Water environment federation. Standard methods for the examination of water and wastewater, 19.

5. American Public Health Association. Water environment federation (1998) standard methods for the examination of water and wastewater.

6. Bradley N., Harrison H., Hodgson G., Kamanyire K., Andrew K. and Virginia M. (2014). Essentials of environmental public health science.

7. Fair GM, Meyer JC, Okun DA (1971). Elements of water supply and wastewater disposal, 2nd edn. John Wiley \& Sons, NY

8. Garg SK (2006). Sewage disposal and air pollution engineering. Environmental Engineering, 18th Edn. Vol. II. Khanna Publishers, New Delhi, pp 228-278.

9. George Tchobanoglous and Franklin L Burton. Waste water engineering. Management, 7:1-4, 1991.

10. GuoqingWu,WeihongBi, JiamingLv, and Guangwei Fu(2011). Determination of chemical oxygen demand in water using near-infrared transmission and UV absorbance method. Chiese Optics Letters, 09(s1):310705.

11. Henry JG and Heinke GW (2005). Environmental science and engineering. Prentice-Hall of India, New Delhi, pp 421-491.

12. Henze, Harremoes, Cour Jansen, E. Arvin (2002). Waste water treatment 
13. Krantz D and Kifferstein B (2007). Leachate characterization and assessment of Ground water pollution near municipal solid waste landfill site.Water pollution and society.

14. Mancy K. H. (2017) Instrumental analysis for water pollution.

15. Mike Cable. (2005). Calibration: A Technician's Guide. ISA.

16. MogensHenze, (2002). Waste water treatment: biological and chemical processes. Springer Science \& Business Media

17. Naima Bradley, Henrietta Harrison, Greg Hodgson, RobieKamanyire, Andrew Kibble, and Virginia Murray. (2014). Essentials of Environmental Public Health Science: A Handbook for Field Professionals. Oxford University Press.

18. Nicholas P Cheremisinoff and Anton Davletshin. (2015).Hydraulic Fracturing Operations: Handbook of Environmental Management Practices. John Wiley \& Sons.

19. Radwan M, Willems P, El-sadek A and Berlamont J (2003). Modelling of dissolved oxygen and biochemical oxygen demand in river water using a detailed and a simplified model. Int J River Basin Manage 1(2):97-103

20. Rounds SA, (2001). Modeling water quality in the Tualatin River: achievements and limitations. In: Warwick JJ (ed) AWRA annual spring specialty conference proceedings, "Water Quality Monitoring and Modeling." American Water Resources Association, Middleburg, Virginia, TPS-01-1, pp $115-120$
21. Tchobanoglous G, Burton FL (1991). Waste water engineering: treatment, disposal and reuse. McGraw-Hill International Edition, pp 1195-1225.

22. Tom Murdoch, Martha Cheo, and Kate O'Laughlin.(1996). The streamkeeper's field guide: watershed inventory and stream monitoring methods.

23. UNESCO (2006). Water a shared responsibility. The United Nations world water development report 2. New York, p 601.

24. T Srinivas. (2008). Environmental biotechnology. New Age International.

25. Villeneuve JP, Hubert P, Mailhot A, Rousseau AN (1998) Hydrological modeling and water management. Rev Sci Eau 11 (Special 10th anniversary).

26. Wayne Boyles. (1997). The science of chemical oxygen demand. Technical information series, Booklet, (9):24, 1997.

27. World Bank (1995). Nigeria strategic options for redressing industrial pollution. World Bank. Industry and Energy Division, West Central Africa Dept. 2, p 76 